\title{
Excessive Use of Consent Decrees by the Brazilian Securities and Exchange Commission
}

\author{
Received: June 27th 2017 • Approved: December 11 th 2018 \\ https://doi.org/10.22395/ojum.v18n37a12 \\ Vinicius Figueiredo Chaves* $^{* *}$ \\ Alexandre Foly Nogueira Sertã** \\ Roberta Maria Costa Santos ${ }^{* * *+}$ \\ Nilton César da Silva Flores*****
}

\begin{abstract}
The main purpose of this paper is to analyze the legal regulation of the Brazilian capital market, through literature research and assessment of documents and data, with focus on the revision of the regulatory instrument known as consent decree (settlement). A total number of 405 terms were approved by the Brazilian Securities and Exchange Commission (CVM) between 2009 and 2014, characterizing a wide use of such regulatory instrument. The present analysis concluded that, although the settlement is considered an important mechanism in the context of capital market regulation, its excessive use constitutes a distortion of both its purposes and of the foundations of normative discipline of the market, and even of the set of functions assigned to the CVM.

Keywords: capital market; regulation; administrative sanctioning proceedings; consent decree.
\end{abstract}

\footnotetext{
The paper is the result of investigations carried out by the authors on issues related to the Brazilian capital market.

* PHD in Business Law from UERJ, Rio de Janeiro, Brazil. Professor at UFRJ, Rio de Janeiro, Brazil; UFF, Niterói, Brazil, and Unesa, Rio de Janeiro, Brazil. E-mail: viniciuschaves@gmail.com

*** Graduate at UFF, Niterói, Brazil. E-mail: alexandre.fsnogueira@gmail.com

${ }^{* * * *}$ Master's in Public Law from Unesa, Rio de Janeiro, Brazil. Professor at Unesa, Rio de Janeiro, Brazil. E-mail: roberta.m.costasantos@gmail.com

${ }^{* * * *}$ PHD in Business Law from UFSC, Florianópolis, Brasil. Professor at UFF, Niterói, Brazil, and Unesa, Rio de Janeiro, Brazil. E-mail: cesarflores2004@hotmail.com
} 


\section{Uso excesivo de los acuerdos extrajudiciales por parte de la Comisión de Bolsa y Valores de Brasil}

\section{RESUMEN}

Este artículo pretende emprender un análisis de las regulaciones legales del mercado capital brasileño apoyado por investigación bibliográfica y evaluación documental y de datos; enmarcada en la revisión del instrumento regulatorio conocido como acuerdo extrajudicial (conciliación). Un total de 405 términos fueron aprobados por Comisión Brasileña de Bolsas y Valores (CVM) entre el 2009 y el 2014, lo cual caracteriza un amplio uso de este instrumento regulatorio. Este análisis concluye que aunque el arreglo presentado acá puede ser reconocido como un importante mecanismo en el contexto de la regulación del mercado de capitales, su uso excesivo constituye una distorsión tanto de sus propósitos como de los fundamentos de la normativa disciplinaria del mercado e incluso del conjunto de funciones asignadas al CVM.

Palabras clave: mercado de capital; regulación, procedimientos de sanción administrativos, acuerdos extrajudiciales.

\section{Uso excessivo de termos de compromisso pela Comissão de Valores Mobiliários}

\section{RESUMO}

Este artigo visa desenvolver uma análise da regulação legal do mercado de capitais brasileiro, apoiada por pesquisa de literatura e avaliação de documentos e dados, com foco na revisão do instrumento regulatório chamado "termo de compromisso". Um total de 405 termos foram aprovados pela Comissão de Valores Mobiliários (CVM) entre 2009 e 2014, que caracteriza um amplo uso desse instrumento regulatório. A presente análise concluiu que, embora o acordo apresentado neste documento possa ser reconhecido como um importante mecanismo no contexto da regulação do mercado de capitais, seu uso excessivo constitui uma distorção de ambos os seus propósitos e das fundações de disciplina normativa no mercado, e ainda de um conjunto de funções designadas à CVM.

Palavras-chave: mercado de capitais; regulação; processo administrativo sancionador; termo de compromisso. 


\section{INTRODUCTION}

The subject of legal regulation of the capital market has been remarkably discussed in past decades, both in legal and in regulatory aspects. In the regulatory aspect, there has been much debate concerning the normative power of regulatory bodies as well as their roles, forms of action and the enforcement of both sanctioning and monitoring functions in connection with the performance of the economic agents in the markets.

In Brazil, the relationship between the regulatory agency of capital market-Brazilian Securities and Exchange Commission (CVM) - and its agents have changed throughout the years, resulting in a tighter proximity due to arising features such as public hearings and the consent decree (settlement), which characterizes a larger aperture of the normative system.

Concerning the consent decree, the law itself empowers agents with the authority to negotiate, even directly with the defendants, in order to lift or terminate proceedings, which constitutes an alternative reaction (consent decree execution) instead of the pure and simple penalties' enforcement (warnings, fines, suspensions, etc.) established by the law.

The academy must not remain idle from such debate, the study of the questions to which it is directly or indirectly related is pressing. Therefore, a new and instigating research line is being inaugurated, having the consent decree as a background to subsidize innumerous theoretical and conceptual discussions from the point of view of reflections that concern the convenience of the decree usage itself, as well as of the adequate form of its enforcement by the regulatory body. The specificity of approaches and analysis herein find their justification in the relevance of the subject.

Therefore, the following research problem is formulated, finding its solution through the following question: Are the legal and regulatory provisions that allow the defendant to propose the consent decree -in the scope of the Sanctioning Administrative Proceeding (SAP)-, enough to make the CVM exaggeratedly approve the substitutive agreements out of opportunity and convenience?

The revision of the published literature concerning the general subject (considering its inherent interdisciplinarity) as well as of the specific cut herein proposed (although subject to few researches), the investigation of both legal and regulatory documents, as well as the assessment, consolidation and analysis of empiric data concerning consent decrees entered by the Brazilian regulatory agency between 2009 and 2014 were consolidated into charts and inserted in the present work, in order to facilitate the readers' comprehension. 
The main purpose of this investigation is to perform an approach regarding the legal regulation of the capital market, based on the critical analysis of the regulatory instrument known as consent decree, in order to subsidize the construction of an answer that satisfies the research problem hereunder.

This paper is divided as follows: i) literature review concerning the roles and segments of the capital market, of the main foundation of the set of legal dispositions that rule such market, as well as of the characteristics of the Brazilian regulatory body (CVM); ii) exam of legal foundations and set of regulations concerning the Sanctioning Administrative Proceeding (SAP), focusing on the mechanism known as consent decree (settlement); iii) gathering of empirical data regarding consent decrees between 2009 and 2014, presenting such data through charts herein inserted, with details concerning the amount of settlements executed each year; iv) critical analysis of the forms of use of the mechanism governed by the CVM.

\section{BRIEF NOTIONS REGARDING THE CAPITAL MARKET}

The capital market comprehends a diversity of transactions involving securities ${ }^{1}$ issued by publicly traded corporations, in order to finance both new or undergoing companies to enable the development of their corporate projects.

The existence of the market supposes an environment that connects a series of economic subjects: on one side, saving agents with excessive resources; on the other, receiving agents, in need of capital, besides those who are simply looking to invest their resources through the acquisition of papers that may bring profitability of invested capital. Thus, the importance in channeling resources towards investments (Vasconcelos \& Garcia, 2005).

The primary share market operates with the securities issued by publicly traded companies, which constitutes the offer of new papers to the investing public (Kümpel, 2007). Issuing companies are also responsible for trading their own papers, using the product of such trade to finance their investments (Assaf Neto, 2012). The main role of this segment consists on raising funds for the economic agents through issuing ${ }^{2}$

\footnotetext{
In Brazil, there is no definition for the term securities. An illustrative list including a series of titles under a variety of natures, such as stocks, debentures, and subscription bonuses has been included in Article 2 of Law 6.385 of 1978, which regulates the securities exchange and created the Securities Commission.

2 Public issuing should be performed, in general, under the intermediation of the integrating institutions of the securities distribution system, known as "intermediaries", such as investment banks, brokering and distributing societies. The aforementioned process is called underwriting, usually undergoing through a pool of institutions for the operation. The participation in question is fundamental for the success of the public issuing, once such institutions directly aid the issuers in the compliance to the demands and requirements formulated by the CVM regarding the distribution offers.
} 
such papers, which may be underwritten by the shareholders of the own company or publicly offered, allowing any investor to acquire them.

On the other hand, the secondary ${ }^{3}$ share market "registers only the transfer of the property of papers already acquired from the companies, thus, not impacting directly the flow of resources available for the issuing companies" (Goulart, Lima \& Gregório, 2006, p. 28, own translation). This business segment allows the investor to convert the investment and transform it back into money (Lameira, 2003), and thus, obtain the return of the invested capital input liquidity ${ }^{4}$ to the papers acquired in the primary market. Therefore, the negotiation market is of vital importance to ensure the success of single issuing and, in a broader view, of the primary share market itself.

\section{THE LAW OF THE CAPITAL MARKET}

The law of the capital market is represented by the set of legal dispositions that discipline the operations carried out therein. According to Kümpel's (2007) doctrine, three main points may be identified as the objects of its regulation; the most relevant being the one that includes the legal organization of specific market segments and the definition of its conditions to negotiate securities, which aims at the protection of its functioning. According to the author, such branch of law belongs to the Economic Law area and is penetrated by public law due to the relevant interest of the collectivity in the existence of markets as effective as possible. Thus, two primary goals are pertinent to the law of capital market regulation: i) the protection of its functioning (priority scope); and, consequently, ii) the protection of the investor.

The protection of the functioning of the market, as a legal asset to be primarily protected, aiming at the maximization of its efficiency, requires a number of adequate measures such as: a) institutional functioning (which consists on the basic conditions for the existence of a series of efficient mechanisms in the different segments of the market through its opening, in such a way that it permits the access of supply and demand, and therefore, allows the channeling of the largest possible portion of

3 The secondary market works mainly in the stock exchanges and market administration institutions in which the transactions involving securities are performed. The stock exchanges integrate the securities distribution system, under the supervision of the regulatory body. Such institutions are responsible for providing an adequate environment for the performance of the securities business, in addition to acting as an auxiliary body in the monitoring of the respective members and of the securities transactions thereunder, as well as preventing the manipulation of prices and detecting unusual movements in the market, besides other functions.

4 The liquidity is an economic concept which, in general, indicates the possibility to transform an asset into money. Such phenomenon is one of the features that makes the capital market so attractive in the eyes of the investors, as it allows them to negotiate its ownership at any time, together with other interested investors. The higher the easiness of negotiation of a certain asset in the market price, the higher its liquidity. 
capitals towards the market as well as their acquisition by economic agents, fulfilling the financing needs of such agents. Regarding the basic legal conditions, it enforces the preservation and enhancement of the investor's trust, which is directly related to transparency, stability, equality in the access to data, justice and integrity of market segments, which would be related to the duty of ensuring isonomic treatment regarding the rights to sensitive information, transparency of the shareholding structure of companies, rules of conduct applicable to the intermediaries of the market, as well as government monitoring of the market); b) operational functioning (related to the necessary reduction of costs for both issuers and investors, considering that such costs impact directly on the decisions of both parties. It is necessary to reduce drastically both costs for the issuing of securities, as well as of the financial burden of the investing agents); and c) placement functioning (in order to ensure that the resources, considering their scarcity, end up flowing into the most developing alternatives that thrust the execution of projects that can change the social reality.

On its turn, the protection of investors as an additional legal asset would unfold in the defense, through the law of capital market: a) a random set of investors: the protection of investing agents, both present and future, considering that the potential for business performance is of extreme importance for the liquidity of the market, and positively reflects on its functionality; and b) exceptional protection of investors' individual concerns through the intent to compensate damages: legal protection in benefit of individual investors, due to its trading businesses, and not of the general public investors (Kümpel, 2007).

The law of capital market, thus, shall include rules arising from the Legislative Power, as well as the regulatory rules created by the specific bodies constituted for the exercise of specific functions in the capital market environment. In Brazil, the regulatory agency of the capital market is the Brazilian Securities and Exchange Commission (CVM).

\section{BRAZILIAN SECURITIES AND EXCHANGE COMMISSION}

The Brazilian Securities and Exchange Commission, created by Law 6.385 of $1976^{5}$, is a federal agency under special regulation that reports to the Treasury Department and has legal personality and its own estate.

According to Moreira Neto (1998), the agency may be described as "an entity of public law from the indirect administration, created by law, functionally decentralized from the State, which performs both its own and specific state attributions, equipped with financial, administrative and patrimonial autonomy" (p. 186, own translation). The

Prior to the creation of the CVM, Laws 4.595 of 1964 and 4.728 of 1965, along with Laws 6.385 of 1976 and 6.404 of 1976 were of high importance for structuring the national financial system. 
author also points out that the most important characteristic relies in the specialization of such bodies and functions in order to comply to certain public interests.

The special regime agency, adverts Gasparini (2009), does not find its legal concept in law, and doctrine has been attempting to exclude it from the legal regime of the agency since it possesses "larger privileges than the normal agencies" (p. 327). According to Nazar (2009), "the law that creates such special regime agencies -without offending any constitutional precepts- grants them specific privileges, such as a higher autonomy, if compared to other agencies" (p. 48, own translation).

The CVM is also an independent administrative authority without hierarchic subordination, it has financial and budget autonomy and its directors have neither a fixed tenure, nor stability. Until its constitution, the Central Bank of Brazil was responsible for the regulation and monitoring of the capital market (Fortuna, 2002), due to a lack of a specific entity to perform such duties.. As to such aspect, the interesting considerations are assigned as follows:

Considering that, at that moment the securities Exchange had a relatively reduced expression, since there was no intention to turn it into a regulatory body of its own, so the Central Bank, whose main attributions were the control of the means of payment and monitoring the banking institutions, became also entitled to regulate such market (White, 1987, p. 23).

It is important to point out that the condition of specially regulated agency only came through the Provisional Measure 8, which was converted into Law 10.411 of 2002, and gave the entity the status of Regulatory Agency (Eizirik, 2011). Until that given moment, it was not uncommon to find authors in the doctrine who would deny such nature.

Moreira (1999), prior to the creation of the referred law, when analyzing the legal nature of the National Monetary Counsel of the Central Bank of Brazil and of the CVM, denied them the status of regulatory agencies with the following terms:

[...] seems inadequate to attribute to such administrative person the title of independent regulatory agencies, considering that the managerial and functional bond with the direct administration prevents such classification. Actually, they are not even Administrative Agencies, but bodies that submit to the traditional concepts of "de-concentration" (CMN) and "de-centralization" (Bacen and CVM). (p. 141)

Once provided by the law with the inherent characteristics of such entities, the CVM was also dispensed with the treatment proportional to its nature, enabling its power to issue regulatory dispositions concerning the securities exchange market in Brazil. In this regard, through the exam of Articles 3, 4 and 5 of Law 6.385 of 1976, Kümpel (2007) clarifies that the jurisdiction of the CVM includes both regulating the 
securities exchange market and permanently monitoring the activities and services carried out in such segment, as well as the dissemination of information concerning both the market itself and those who take part in its operations, as well as the securities traded therein.

Considering the purpose of its functions, in a broader way, the CVM shall perform them in order to: i) ensure the efficient and regular functioning of both the securities and counter markets; ii) protect the owners of securities from irregular issuing and illegal acts carried out by officers or controlling shareholders from companies or also managers of securities portfolios; iii) prevent or forbid fraudulent practices or manipulations intended to create artificial conditions for supply, demand or for the prices of the securities traded in the market; iv) ensure public access to information concerning the traded securities and their issuing companies; v) ensure the observance of equitable trading practices in the securities market; vi) stimulate savings and their application in securities; vii) promote the expansion of the stock market as well as its efficient and regular functioning, and stimulate the permanent applications in the capital stock of public companies.

The CVM -created with the purpose of disciplining, monitoring and developing the capital market- has, in its regulatory function ${ }^{6}$, one of its main capacities ${ }^{7}$. Through autonomy and agility, the CVM shall regulate both dynamic and complex economic and financial relations therein undergoing ${ }^{8}$, guiding its activities with a set of principles based on a series of foundations identified as key-factors for the promotion of the

6 In the doctrine it is possible to find authors that asses the difference between ruling and regulation. In this present work, the broad sense of regulation will be considered in a wider manner, including both ruling and regulation in their strict sense. Regarding the subject, it is interesting to point out the position of Rosa (2012), for whom the capacities attributed to the CVM may be defined as hybrid, including both ruling and regulation. When ruling, the agency would be detailing the content of the principles and rules stipulated in Laws 6.385 of 1976 and 6.404 of 1976. In opposition, when regulating, it would fill eventual gaps or omissions in such legal documents. According to the author, the regulatory power, called supplementary capacity, reveals itself in the "possibility of the CVM to integrate the legal system, in order to fulfil normative gaps arising out of new situations in the capital market, when the upcoming complexity and dynamism could not be foreseen by the primary legislator". (p. 103, own translation). The author proceeds pointing out that the regulatory power "shall be exercised within the limits imposed by Article 4 lof Law 6.385 of 1976, as marked] and of the Federal Constitution" (p. 103, own translation).

7 It is important to point out the definition brought by Medauar (2002) whom, although signaling the meaning of the term in its broadest sense, ends up listing a series of powers that are mistaken for those attributed to the CVM: "We understand that the regulation, in its current context, includes: the creation of norms; the monitoring of its enforcement; the attribution of qualifications (i.e. authorization, permission, concession); the imposition of penalties; the mediation of conflicts (both to prevent and to solve, making use of a variety of technics, such as: public consultation, public hearings, execution of a compromise to cease and adjustment settlement)" (p. 126, own translation).

8 According to Aragão (2001), "the laws that grant normative power to the independent regulatory entities have low normative density, in order to provide the development of sectorial norms apt to, under autonomy and agility, rule the dynamic and complex subjacent social reality" (p. 104, own translation). 
fundamental conditions for its expansion and development. Such purposes depend on the efficiency and reliability of the market, reflected on the ensuring of adequate levels of protection and harmony amongst the concerns of all trading agents of the market. The foundations aforementioned may be postulated through the following five aspects:

1) General public interest: The transfer of resources between investors and economic agents is crucial for the continuous formation of capital when considering a society, such as the Brazilian, which clearly opted for the capitalist model based on free enterprise and on a market-oriented economy. Such a transfer of resources, causes investment and growth of economic units and, in a broader way, of the society as a whole. Therefore, the regular functioning of the securities exchange market is of general public interest.

2) Reliability: The existence and growth of the market depends on the trust that its various agents have on the system. If the purpose of the regulatory body is to favor the development of the market in order to ensure its adequacy with the growing demands of society, it becomes imperative to observe such purpose. The regulation should be carried out in order to create a reliable foundation that guarantees to the owners of savings accounts that the trade in the market environment brings nothing more than its own risks.

3) Efficiency of the market: One of the many features regarding the free market is its ability to function as a mechanism able to direct the savings of a society towards financing projects in order to better adequate itself to its expectations. This aspect has to be observed and sought during the regulatory work, considering that only through such work it is possible to best meet the needs of the society. Equally, decreasing costs related to the mediation of such resources meets both the needs of companies and of individual investors, and it shall be through the efficiency of the market that such purposes should be achieved: locating and operating efficiencies.

4) Competitiveness: The efficiency of the market depends on the level of competition established among its participants. Therefore, the regulation has to keep its attention on such fundament, not only to prevent actions that may cause a decrease in competitiveness, but also ensuring its health. Besides, active competition reduces the need for regulation.

5) Free market: The freedom of action and of access to its mechanisms is a precondition for the existence of a market able to suitably perform its functions. In the process of regulation of securities markets, it is mandatory to ensure the presence of both the respect to the free flow of the forces of the market and the free access to the performance of activities and operations thereunder. 
The analysis of the abovementioned fundaments brings to the conclusion that the regulatory role of the agency comprises not only one, but many objectives, which may be seen as complementary. Such conclusion is clear in the doctrine of Cantidiano (2005), for whom the activity of the regulatory body accommodates at least four main scopes, which are described below:

The entire activity performed by the regulatory body has the finality of: (a) stimulating the creation of savings and its application in securities; (b) promoting and ensuring the expansion and functioning of the securities market in an efficient and regular way; (c) protecting the securities owners and the investors against: (i) irregular issuing of securities; (ii) unlawful performances by administrators, controllers of companies and savings managers; and (iii) the use of relevant information not yet disclosed to the market; and (d) ensuring the observance of the proportionate trading practices in the market.

In order to carry out its normative, monitoring and sanctioning functions, the CVM is endowed with police power, through which it can limit the individual liberty in favor of public or collective interests. Thus, the agency has both material and institutional means at its disposal for the regular performance of its attributions, having the responsibility, for example, to initiate sanctioning administrative proceedings ex officio.

\section{THE CONSENT DECREE IN THE SANCTIONING ADMINISTRATIVE PROCEEDINGS}

The fundaments and finalities of the legal discipline of the capital market point to the necessity of maintenance of an environment of respect of legal (examples: Laws 6.385 of 1976 and 6.404 of 1976) and regulatory (examples: normative instructions issued by the CVM) frameworks, as well as the proportionate practices by administrators, fiscal counselors and shareholders of publicly traded companies, mediators and other participants of the market.

Therefore, Law 6.385 of 1976 endows the CVM with the legal duty to apply a series of penalties to offenders, amongst which may be found subpoenas, fines, suspensions, temporary impediments and prohibitions and/or cancellation. The application of such penalties occurs after assessment and verification, via sanctioning administrative proceedings (SAP), of the violating actions both in the legal, regulatory and proportionate practices frameworks. It must be pointed out that the penalties should have educational and preventive effects for the participants of the market.

The abovementioned Law, in its Article 11, paragraph 5, states that the regulatory body may -at its own discretion- if permitted by the public interest, suspend the installed administrative procedure in any stage, for the assessment of offenses to the 
securities exchange market if the investigated offender executes the $C D$ (settlement), and undertake the obligations to: i) stop the practice of activities or actions deemed unlawful by CVM; and ii) correct the irregularities pointed out and provide the necessary compensation for the damages occurred.

The SAP shall observe the proceeding established by CVM itself in the exercise of its normative power. Currently, it is disciplined by Deliberation 538 of March $5^{\text {th }}$, 2008, with the amendments brought by Deliberation 552 of 2008 (which regulates the ordinary proceeding), and also the Instruction 545 of 2014 (which regulates the summary proceeding), which regulate the proceedings to be observed in the event the SAP is installed by the agency.

Both in Deliberation 538 (Article 13, paragraph 4) and in Instruction 545 (Article 2, paragraph $2, \mathrm{VI})$, the subpoena shall include a notice regarding the prerogative of the accused of executing a CD, except in event of the assessment of irregularities related to Law 9.613 of 1998 (which regards crimes of money laundering, concealment of assets, rights or values; the prevention of the use of the financial system for the practice of the unlawful acts prescribed by this law, and creates the Financial Activities Control Counsel-FACC), as well as the cases regulated by Instruction 301 of 1999 of CVM.

The CD is ruled by the Deliberation 390 of 2001 (amended by Deliberation 486 of 2005), which regards the proceedings of the aforementioned institute, through Ordinances PTE 71 of 2005 and PTE 066 of 2008, both from the CVM.

As noted by Wellisch E Santos (2009) the North American consent decree would be the main inspiration for the Brazilian version of the instrument. Besides the influence of the consent decree noted by the authors, it is possible to say that the Brazilian consent decree has similarities with the commitment to cease the investigated practice present in the Antitrust Law (12.529 of 2011) and also, in the conditional suspension of the criminal proceeding prescribed by Law 9.099 of 1995.

\section{DYNAMICS OF THE CONSENT DECREE}

Except when of the assessment of the irregularities in connection with the Law 9.613 of 1998 or in the event of cases prescribed by Instruction 301 of 1999 of the CVM, the agency is authorized to execute the $\mathrm{CD}$ within and undergoing SAP, as prescribed by Article 1, paragraph 1 of Deliberation 390 of 2001 of the CVM.

The interested party in the execution of the $\mathrm{CD}$ might present a written proposal to the CVM, undertaking the obligation to: i) stop the practice of activities or actions 
deemed unlawful, if the case may be; and ii) correct the identified irregularities and compensate for the damages caused to the market or to the CVM.

The interested party shall disclose the intent of execution of the CD until the deadline of the defense arguments, notwithstanding the burden of presenting such arguments. However, the aforementioned disclosure is also permitted in the preliminary investigation stage. In the first case, the full proposal shall be addressed to the Administrative Proceedings Control Coordination (APCC) in no longer than 30 (thirty) days as of the presentation of the defense. In the second case, it shall be addressed to the Superintendence responsible for the investigation.

The Federal Specialized Prosecutor's Office (FSP) of the CVM shall be heard about the legality of the proposal presented by the interested party. After the manifestation of the FSP, the General Superintendent shall submit the proposal of execution of CD to the Consent Decree Committee $(\mathrm{CDC})^{9}$, which shall opine on the matter (in no longer than 30 days of the presentation of the opinion of FSP) regarding the opportunity and convenience of the execution, the adequacy of the proposal formulated by the accused; proposing to the Body its acceptance or denial also considering the opportunity and convenience, the nature and severity of the offenses object to such proceeding, the accused priors and the effective possibility of penalty in the particular case.

Prior to the preparation of its opinions, the CDC -at its convenience- may negotiate the most adequate conditions with the proposer. Such negotiation between the CDC and the proposer shall be concluded in no more than 60 (sixty) days, being the Committee able to, at the end of negotiations, amend the initial proposal, if prior to the deadline imposed by the Committee. May this be the case, the deadline for the preparation of the opinions of the Committee shall be counted as of the date in which the negotiations were concluded or as of the presentation of the amendments to the initial proposal.

The execution proposal, together with the opinions of the CDC, shall be submitted to deliberation by the Body, which shall come to a decision regarding its acceptance or denial. If accepted, the decree shall be presented by the President of the CVM, the interested parties along with two witnesses. The CD shall suspend the current administrative proceeding for the period stipulated for the fulfillment of the

9 The current composition of the Committee is disciplined in Article 2 of Ordinance CVM PTE n. ${ }^{\circ} 71$, of August 17th, 2005, with text provided by Ordinance CVM PTE n. ${ }^{\circ}$ 066, of April 1st, 2008. Article 2 - The Consent Decree Committee shall be comprised of the owners of the following Superintendencies: i - General Superintendency - GS; ii - External Monitoring Superintendency - EMS; iii - Corporate Relations Superintendency - CRS; iv - Market and Intermediaries Relations Superintendency - MIRS; $\mathrm{v}$ - Auditing and Accounting Regulations Superintendency - AARS; and vi - Sanctioning Proceedings Superintendency - SPS. 
settlement. On the other hand, the conditions of the decree, after accepted by the Body, shall not be amended, unless a new deliberation is carried out by request of the interested parties.

The execution of the consent decree shall not imply a confession as to the matter of fact, nor acknowledgement of the unlawful conduct assessed in the proceeding that originated it, being those the most relevant advantages for the accused.

From the decision of the Body that denies the proposal for $C D$ there shall be no appeals to the Resources Counsel of the National Financial System, since the discretion to accept or deny the execution of the decree is entirely of the agency, pursuant to the Article 11, paragraph 5 of Law 6.385 of 1976.

\section{ANALYSIS OF THE MAIN THEORETICAL AND PRACTICAL ASPECTS OF THE CONSENT DECREE}

According to Silveira (2006), the judicial nature of the CD is similar to the one of the transaction, once it constitutes a deal between the accused and the CVM. As a matter of fact, the settlement may be understood as legal business, considering that it combines features from both civil transaction and discretionary ${ }^{10}$ administrative act, in which the Administration is endowed with a certain liberty to assess or decide.

The nature of legal business is clear in the analysis of Muto \& Yokoi (2008), for whom it is a role of the CVM to accept the proposed terms, deny or even discuss amends, as typical options of the agents that seek to perform legal businesses, but without the necessity of legal approval of the eventually performed decree. It is important to emphasize that the dynamics of the consent decree in Brazil are different, for example, from the one present in the North-American model, in which the efficiency of the consent decree depends on the judicial approval.

Through the $\mathrm{CD}$ it is possible to compensate the investors that suffered damages even if they are not parties in the proceeding. Eizirik (2011) teaches that the demand for compensation only occurs in the event of any quantifiable damage or against identifiable damaged individuals so it may be possible to attribute to each their own due compensation. In this respect, it is duly noted that the Article10 of the Deliberation 390 of 2001 prescribes that, in the event of damages to investors, the CVM may, at its discretion, notify such investors to present further information regarding the quantification of the value to be paid in compensation.

10 Administrative act is the unilateral declaration of the State in the exercise of public prerogatives, expressed through complementary concrete commands of the law issued in order to enforce its fulfillment and subject to legitimacy control by the jurisdictional body (Mello, 2003). 
In the abovementioned case, the harmed investor shall refrain from presenting information further than the extent of the damages suffered and the value of compensation. Nevertheless, in the event of undetermined or unidentifiable harmed investors, the agency may, by common consent with the proposer and at his expenses, publish summons in order to determine and identify such harmed investors and thus reach the quantification of the individual values to be paid as indemnification.

Silveira (2006) emphasizes that until 2006 the main obligations imposed to the proposers in the accepted consent decrees were: donating to charitable institutions; recomposing data to harmed investors along with the costs incurred by the CVM in connection with the administrative proceeding, implementation of internal negotiations policy in trading securities with publicly traded companies; performing trainings and seminars and distributing materials regarding applicable regulations, with educational scope as well as perform public offerings for the papers and for the acquisition of shares from the minority shareholders that do not adhere to the public offering.

For the enforcement, the CVM may carry out judicial enforcing of the decree, which is an extrajudicial executable title, pursuant to Article 11, paragraph 7 of Law 6.385 of 1976, together with the restart of the sanctioning administrative proceedings, suspended by occurrence of the settlement. Such conduct is not considered bis in idem, once the consent decree does not apply penalties, but imposes obligations (Moraes, 1999).

Prior to its amendments by Law 10.303 of 2001, the final part of paragraph 7 of the Article 11 of Law 6.385 of 1976 prescribed that the non-fulfillment of the consent decree implies in contempt, pursuant to Article 330 of the Criminal Code. The doctrine criticized such paragraph. According to Eizirik (2011), the crime was not configured, no orders were issued by the CVM as of the execution of the consent decree. Considering the negotiating nature of the decree, there is no order, but solely a simple agreement.

Another important question, emphasized by Silveira (2006) is that the non-compliance of the consent decree may not be considered as an aggravating circumstance by the CVM in the application of penalties if the accused, for not complying with the settlement, is condemned in the sanctioning administrative proceeding. The claim is that the settlement solely imposes the suspension of the SAP installed against the accused, therefore, the penalization of the accused, after the assessment of illegality in the practices pointed out by the CVM as infractions could not be aggravated by the non-compliance of the decree.

Once there is a confirmation that the settlement entered into by CVM and the accused arose out of a legal defect, thus not brought by convenience and opportunity 
criteria, any interested party may request in court the deconstruction of the consent decree entered into. However, the deconstruction based on legal defect does not exclude the possibility to execute a new decree, free from defects (Silveira, 2006).

Throughout the years, the modalities of obligations assumed by the consenting parties have been altered. In the beginning, the obligation leaned towards the offering of seminars or to elaborating educational material to be distributed amongst the investors. As of the year 2000, it may be noted that many consent decrees contained the commitment to make donations to social programs and philanthropic entities. In 2005, there was an increase in the values attributed to the CVM as a form of compensation for expenses, donations, fines, and damage repair caused to the agency or to the capital market. After 2006, the obligation to pay a determined amount to the CVM, without specification of the reason, became more frequently noted (Tanji, 2009).

Such as prescribed by the relevant legislation, the CVM may reject the proposal of consent decrees. In the year 2005, a data survey regarding the enquiries to determine the reasons that lead the CVM to reject or accept the consent decree concluded that: in the event of approval, the decision was based mainly on convenience and opportunity, with emphasis on the compensation for the damages as a relevant factor for the acceptance of such decree. On the other hand, in the event of rejection, the decision was based mainly on the lack of convenience or opportunity and of the compensation for the caused damages. Furthermore, the third reason was the failure to undertake a commitment related to the supposedly irregular practice when executing the decree, considering that such practice is deemed mandatory by the regulation itself (Silveira, 2006).

On January $15^{\text {th }}$ of 2009 , a research contemplating 184 consent decrees entered into and settled by the CVM between the years 1998 and 2008 was published, exposing the increasing level of compliance with the obligations therein. Only one non-compliance was detected (IA CVM 04 of 1999), according to Tanji (2009), it was followed by a: "(i) ruling by the body of the CVM with the application of administrative penalties, (ii) promotion of public action by the Federal Public Ministry in face of the promissory parties, in which the CVM acted as assistant to the accusation" (p. 101). (own translation). This case (Process n. ${ }^{\circ}$ 2004.61.00.019427-5) was processed at the $5^{\text {th }}$ Federal Civil Court of the Judiciary Subsection of the Capital of the State of São Paulo.

In practice, many consent decrees have a high monetary value, nevertheless, there are defendants that, even aware of their innocence, choose to execute the decree and pay in an attempt to both maintain their good reputation, once the pending administrative matters may represent an obstacle to good business oppor- 
tunities, and also to prevent the risks of convicting sentence (Carrion, 2011). It must be noted that "the value received by the damaged party, even though relevant, is still considerably lower than the amount received by the CVM" (Tanji, 2009, p. 102). (own translation).

In an interesting exercise of application of the thesis/antithesis methodology, the magazine Capital Aberto published two opinions, in which the authors were proposed to face the following question: Are the consent decrees being used too largely by the CVM? According to Chaves (2010), the decrees have been excessively used by the agency, which reflects the need of more thoroughness in the approval of the settlements. In the opinion of the author, in severe cases -as in the event of the practice of improper use of relevant information- there should be no possibility of executing a consent decree.

In opposition, Amendolara (2010) denies the excessive use, as far as it represents an effective instrument which, in practice, prevents law suits that are often dragged through long periods and show no guarantee of conviction to the damaging parties.

\section{THE CONSENT DECREE IN THE PERIOD BETWEEN 2009 AND 2014: EXCESSIVE USE OF THE REGULATORY INSTRU- MENT}

The methodological option for the research about empirical data regarding the instrument was made in order to achieve a better evaluation of the $C D$ as a regulatory instrument in the Brazilian capital market.

Considering the need of a cut, the period between 2009 and 2014 was more profoundly analyzed, even though the instrument has been used since 1998 (just the year after its introduction to the legal system in 1997). A deeper analysis, found in the doctrine approaches regarding the subject, which was majorly indexed information related to the period prior to 2009. Therefore, the proposed cut would allow a more updated view of the recent dynamics of the use of such instrument.

In that sense, the CD's approved in the years 2009-2014 were obtained via research through the CVM files. It is important to highlight that: i) there are cases in which the settlements "approved" in a given year are only executed in the following year, therefore, only those approved until the end of the cut were counted; ii) in many cases, there is more than one settlement approved in connection with the same SAP.

The obtained data was consolidated and transferred into the two graphics that follow, which, according to the adopted methodology, show the annual quantity of settlements approved by the regulatory body in each year of the selected periods. 


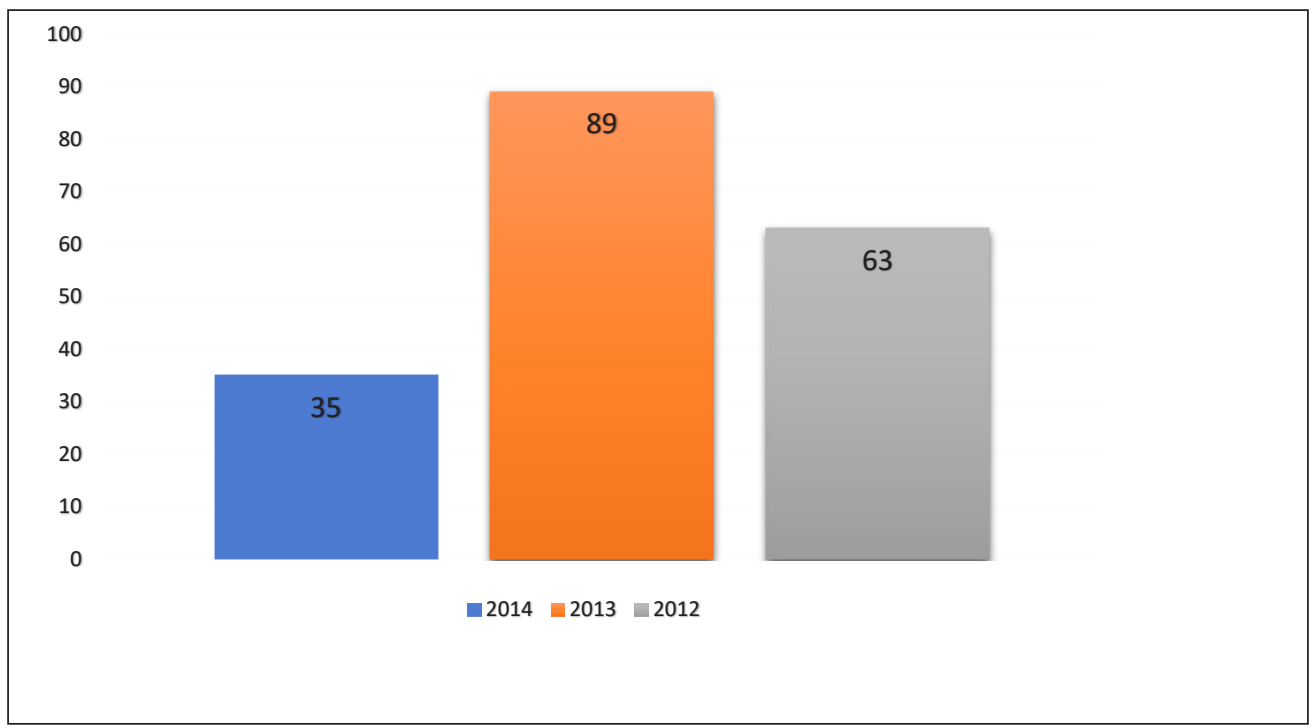

Figure 1. Approved consent decrees 2012-2014

Source: own work

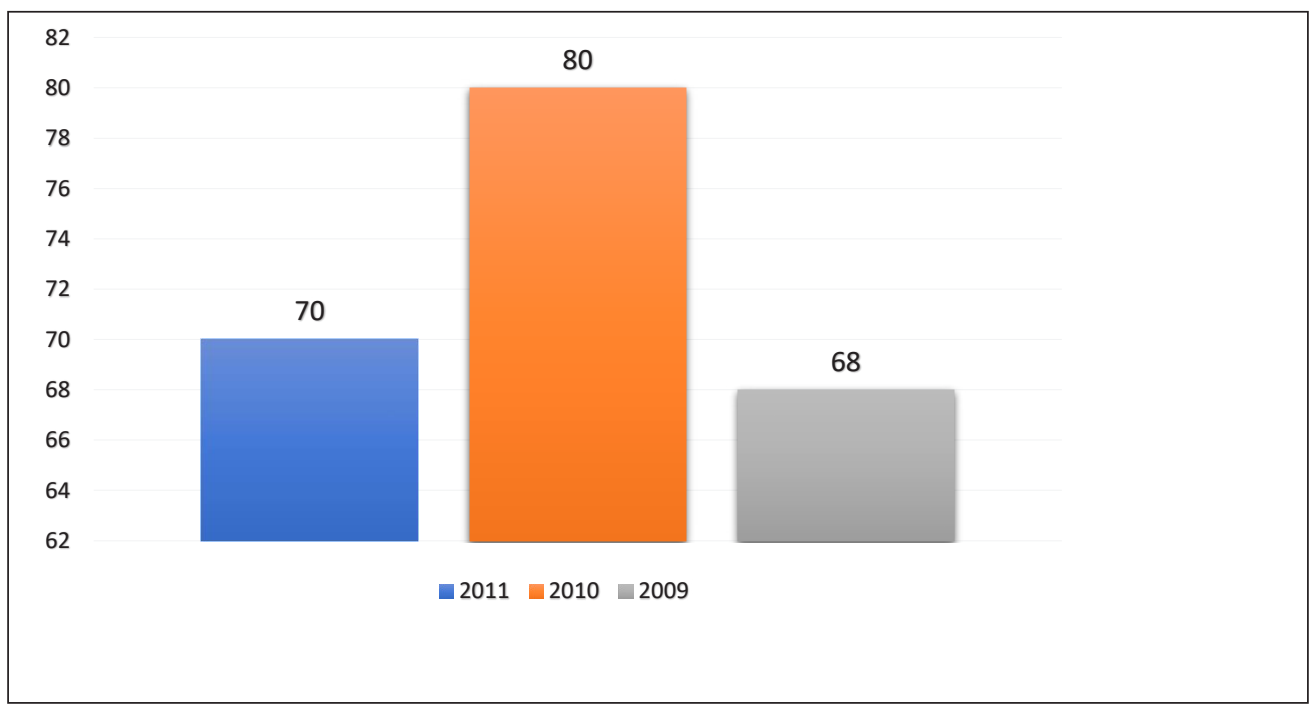

Figure 2. Approved consent decrees 2009-2011

Source: own work

Considering the consolidated data in the graphics, it is clear that there is an excessive use, by the CVM, of the permission to execute the settlement, as an alternative both to the application of the penalties prescribed by Law 6.385 of 1976, to the substitutive agreement entered into with the offenders of the legal and regulatory frameworks 
as well as of the equality of the practices carried out in the capital market. Cases in which the settlement propositions were rejected by the agency ${ }^{11}$ were also registered.

The data indicates that the settlement, being understood as an important mechanism in the scope of capital market regulations -since it characterizes a larger aperture of the normative system to the market agents and ensures space for alternative reactions to the pure and simple application of penalties- allows negotiations between the agency and the defendants which may cause the suspension or even the termination of law suits, the imposition of compensations, etc. Nevertheless, its excessive use implies a distortion of both its finalities, and of the fundaments of the normative discipline of the market as well as of the set of functions assigned to the CVM.

The CD should not be vulgarized in such a way that it constitutes a type of authorization/incentive to the practice of offenses, promoting the general knowledge that it would suffice for the offender to execute the decree, immediately after the offense, and be solely committed to cease the practice of unlawful activities or actions, correct the appointed irregularities, and compensate the damages.

Reliability, one of the foundations of the regulation, indicates that the normative discipline of the market should be carried out in order to create a trustworthy base that provides the savings owner with the guarantee that he may act exclusively under the risks of the own business in which he chooses to operate. Offenses to the regulatory framework corrode the trust of investors in the market, and a market shall never be effective if there is no trust in the regular functioning to which the compliance with the set of rules is mandatory.

In the same way, the role of the CVM should be to discourage unlawful practices, watch the protection of the owners of securities against the irregular issuing and unlawful acts from administrators, controlling shareholders or managers of securities' portfolios as well as to avoid or prevent modalities of fraud or manipulations intended to create artificial conditions of demand, supply or price of securities traded in the market besides ensuring access for the public to the information regarding the traded securities and the issuing companies in connection to such securities, ensure

11 In the analysis of the proposal for consent decree in connection with the sanctioning administrative proceeding RJ2012/9808, the Body, in 01/06/2015, unanimously deliberated as inopportune and inconvenient to accept the proposal, since the eventual execution of the consent decree together with the defendants would not represent a significant economy in the proceeding to the CVM, the presented proposals were rejected. Another important point: the recurrence is one of the reasons that causes CVM to refuse the proposal for consent decrees, such as occurred in June 17th 2015, when the Body unanimously decided to reject the proposal for consent decree made by the Federal Government, which was accused of failure to comply with the provisions of Article 115 of the Stock Corporation Law, arising out of its participation in the Extra-ordinary General Meeting that deliberated for the acceptance of the terms of the Provisional Measure 579 - which caused damages to the state company. 
the observance of isonomic trading practices in the securities market, stimulate the creation of savings and its application in securities, promote the expansion and efficient functioning of the stock market and stimulate the permanent applications in the shares of the capital stock of the publicly traded companies.

It must be highlighted that the penalties for the practice of actions that offend the legal and/or regulatory frameworks or the isonomic practices should provide a larger educational and preventive effect to the agents of the market, in order to prevent future unlawful practices. It is possible that, through the excessive use of the settlement, an exactly opposite effect may be created, or even the dissemination of the idea that the offending actions and non-isonomic practices may be "erased" through the execution of a consent decree. Such possible negative effect is corroborated by the very legal discipline of the subject, indicating that the settlement, once proposed, accepted and complied with, shall not constitute a confession as to the matter of fact, nor a recognition of the unlawfulness of the analyzed conduct.

\section{CONCLUSIONS}

According to the present research, it is possible to comprehend the CD as an important regulatory mechanism to be used by the regulatory body of the Brazilian capital market, the CVM.

Through such instrument, agreements may be reached between the agency and the offenders of the legal and regulatory frameworks, or even with the responsible for the performance of non-isonomic practices in the market. The decrees constitute an alternative to the penalties prescribed by Law 6.385 of 1976, constituting an open normative system that allows a higher proximity between the regulatory body and market agents.

As an answer to the research problem that oriented this present investigation, it is believed that the provisions that allow the proposition of the consent decree are not the reason why the exaggerated use of the decrees is opportune or convenient. Considering its nature of regulatory instrument, its use should be restricted to the foundations that inspire the regulatory framework, such as public interest, reliability and efficiency of the market. In the same way, the CVM, should be limited by the respect for the institutional finalities of the decree, such as the protection of the owners of securities, the prevention or prohibition of fraud or forms of manipulation the ensuring of the observance of isonomic trading practices in the securities market the stimulation of the creation of savings and its application in securities, the promotion of the expanded, regular and efficient functioning of the market as well as the permanent investment in the shares of the capital stock from the publicly traded companies. 
By the examination of the SAP's installed between 2009 and 2014, a final number of 405 decrees approved by the regulatory body was reached. A result that characterizes an increasing utilization of this regulatory instrument. The exaggerated use of such alternative may either implicate a distortion of the objectives the settlement itself, considering that its nature should be as of a mechanism of regulation, or a violation of the foundations of the normative discipline of both the market itself and of the set of functions assigned to CVM.

Therefore, the use of the CD must be restricted to punctual cases that the alternative to the application of the penalties prescribed by the law reflects the public interest, and taking into account the foundations of the regulations/finalities of the CVM itself.

Therefore, the following points may constitute a new directive for the agency, as an incentive to new forms of settlements: i) as a general rule, the use must be restricted to cases prescribed by the Instruction CVM 545 of 2014, which applies the SAP in its summary rite for the assessment of the possible objective offenses, related to a neglecting conduct of the market agents; ii) as an exception and through a higher thoroughness, the instrument may be used in the event of certain generally lighter offenses (in which case the application would obey Deliberation CVM 538 of 2008, which regulates the SAP in its ordinary right), and also being forbidden in the event of grave offenses such as the irregular use of relevant information.

\section{REFERENCES}

Amendolara, L. (2010). Instituto eficaz. Revista Capital Aberto, 78, 46 47.

Aragão, A., S. (2001). O Poder Normativo das Agências Reguladoras. Revista Trimestral de Direito Público, 36, 88-113.

Assaf Neto, A. (2012). Mercado financeiro. São Paulo, Brazil: Atlas.

Cantidiano, L., L. (2005). O Papel Regulador da CVM. Revista de Direito Bancário e Mercado de Capitais, 27 (8), 38-41.

Carrion, B., M. (2011). Por que os cada vez mais milionários termos de compromisso se tornaram uma saída conveniente para a CVM e para os acusados. Revista Capital Aberto, 91, 44.

Chaves, R. (2010). É preciso mais rigor. Revista Capital Aberto, 78, 46-47.

Comissão De Valores Mobiliários (2013). O Mercado de Valores Mobiliários Brasileiro. Rio de Janeiro: CVM/ SOI.

Eizirik, N. (2011). Mercado de Capitais - regime jurídico. Rio de Janeiro, Brazil: Renovar. 
Fortuna, E. (2002). Mercado financeiro: produtos e serviços. Rio de Janeiro, Brazil: Qualitymark.

Gasparini, D. (2009). Direito Administrativo. São Paulo, Brazil: Saraiva.

Goulart, A., M., C., Lima, G., A., S., F., E Gregório, J. (2006). Mercado de renda variável. In I., S. Lima, G., A., S., F., Lima \& R., C. Pimentel (Eds.), Curso de mercado financeiro: tópicos especiais (22-67). São Paulo, Brazil: Atlas.

Kümpel, S. (2007). Direito do Mercado de Capitais - do ponto de vista do direito europeu, alemão e brasileiro. Rio de Janeiro, Brazil: Renovar.

Lameira, V., J. (2003). Mercado de Capitais. Brazil, Rio de Janeiro: Forense Universitária.

Medauar, O. (2002). Regulação e Auto Regulação. Revista de Direito Administrativo, 228, 123-128.

Mello, C., A., B., (2003). Curso de Direito Administrativo. São Paulo, Brazil: Malheiros.

Moraes, L., R. (1999). Considerações sobre o consent decree e sua aplicação no âmbito da disciplina do mercado de valores mobiliários. Revista de Direito Bancário e do Mercado de Capitais, 4, 99-113.

Moreira, E. B. (1999). Conselho Monetário Nacional, Banco Central do Brazil e Comissão de Valores Mobiliários. Considerações acerca de sua natureza jurídica, em face das chamadas "Agências Administrativas". Revista de Direito Mercantil, 116(38), 136-150.

Moreira Neto, D. F. (1998). Curso de direito administrativo: parte introdutória, parte geral e parte especial. Brazil, Rio de Janeiro: Forense.

Muto, S., \& Yokoi, Y. (2008). Colegiado da CVM amplia o uso de termos de compromisso. Revista Capital Aberto, 60, 8.

Nazar, N. (2009). Direito econômico. Bauru, Brazil: Edipro.

Rosa, M., E., F. (2012). O Poder Normativo da Comissão de Valores Mobiliários (Dissertação de Mestrado). Universidade do Estado de São Paulo, São Paulo, Brazil.

Silveira, S., M., B. (2006). O Instituto do Termo de Compromisso no Sistema de Regulação do Mercado de Capitais Brasileiro (Dissertação de Mestrado). Pontifícia Universidade Católica, São Paulo, Brazil.

Tanji, M. (2009). Mercado de capitais brasileiro e tutela coletiva dos interesses (Dissertação de Mestrado). Universidade de São Paulo, São Paulo, Brazil.

Vasconcelos, M., A., S., E Garcia, M. E. (2005). Fundamentos de Economia. São Paulo, Brazil: Saraiva.

Wellisch, J., S., M. E Santos, A., P. (2009). O termo de compromisso no âmbito do mercado de valores mobiliários. Interesse Público, 11(53), 137-150.

White, M., C., I. (1987). A nova constituição e a regulamentação do sistema financeiro. Revista da CVM, 15, 19-28. 